\title{
1. The extensive use of tax and direct expenditures over fiscal and market instruments in environmental policy
}

\subsection{INTRODUCTION}

This chapter provides a general overview of the coverage of the book. It sets the stage for the issues and analysis that will be examined in this book by outlining the extent to which the use of spending instruments has prevailed in environmental policy when compared with market-based instruments. It also outlines the key themes and issues that will be examined in the book and explains the approach that will be adopted in carrying out the analysis.

\subsection{THE CONTEXT}

The conventional view among economists is that the capacity of market-based instruments (environmentally related taxes and tradable permits) to place a price on the costs of environmental harmful activities makes them the most efficient instrument for encouraging firms to achieve pollution abatement at the lowest cost. Much has been written about the role that these instruments play in internalising such costs, and for this reason an examination of such taxes at any level of detail will be outside the chosen focus of this book. In spite of this, several studies have revealed that their use in the contemporary environmental context has been rather limited. The analysis in Chapter 3.1.2 of this book attempts to unravel some of the reasons for the rather limited use of market-based instruments and taxes in environmental policy, in comparison to the extensive use of spending instruments (tax expenditures and direct expenditures). Indeed, these studies have consistently found the prevailing regimes for taxing energy use and carbon emissions to be ineffective. The OECD report, 'Taxing Energy Use 2018', which examined patterns of energy taxation in 42 OECD and G20 countries (representing approximately 80 per cent of global energy use), over the $2012-15$ period, revealed that energy taxes were poorly aligned with the environmental and climate costs of energy 
use. ${ }^{1}$ As a result, they provided only limited incentives to reduce energy use, improve energy efficiency, and drive a shift towards cleaner forms of energy. In non-road sectors, which collectively account for 95 per cent of carbon emissions from energy use, 81 per cent of carbon emissions were untaxed. In cases where taxes were imposed, they were too low to combat global warming, when compared to the benchmark level of $€ 30$ per ton of $\mathrm{CO}_{2}-$ (a conservative minimum estimate of the damage from emitting one ton of $\mathrm{CO}_{2}$ ). The report revealed that taxes on coal were close to non-existent, and that even though energy taxes in the road transport sector were higher than other sectors, it was not enough to cover the negative side effects of energy use. Commenting on the disconcerting nature of these findings, OECD Secretary-General Angel Gurria stated: 'Efforts have been made, or are underway in several jurisdictions to apply the "polluter-pays" principle, but on the whole progress towards the more effective use of taxes to cut harmful emissions is slow and piecemeal. Governments should do more and better.'2 A 2019 IMF Working Paper also decried the fact that the under-pricing of fossil fuels remained pervasive and substantial. $^{3}$

In terms of their overall coverage, a 2013 OECD study reports that only 7 per cent of global $\mathrm{CO}_{2}$ emissions are subject to a carbon price. ${ }^{4}$ This finding is supported by a later World Bank report, which estimates that current and scheduled $\mathrm{CO}_{2}$ pricing instruments account for about 13 per cent of annual global GHG emissions. ${ }^{5}$ The implications of these findings are that over 85 per cent of annual global GHG emissions are covered by subsidies and direct regulation.

The gap created by the failure to use market instruments to address the challenges of environmental degradation, has to a large extent, been filled by governments relying on public spending instruments. This has been the case even though the capacity of tax expenditures to internalise negative externalities into prices is rather limited. One of the underlying themes pursued throughout

1 OECD, Taxing Energy Use 2018: Companion to the Taxing Energy Use Database (Paris, OECD, 2018); see also OECD, Effective Carbon Rates on Energy: OECD \& Selected Partner Economies (Paris, OECD, 2015).

2 OECD, 'Governments should make better use of energy taxation to address climate change', OECD, Newsroom, 14 February 2018.

3 David Coady, Ian Parry, Nghia-Piotr Le, and Baoping Shang, 'Global Fossil Fuel Subsidies Remain Large: An Update Based on Country-Level Estimates', IMF Working Paper WP/19/89 (IMF Fiscal Affairs Department, May 2019).

4 OECD, 'Climate and Carbon: Aligning Prices and Policies', OECD Environment Policy Paper no. 1 (OECD, 2013), 11; OECD/IEA, 'Redrawing the Energy-Climate Map' World Energy Outlook Special Report (OECD/IEA, 2013) 11.

5 World Bank, State and Trends of Carbon Pricing 2018 (Washington DC, 2018) 22. 
this work seeks to uncover the factors that explain the predilection on the part of governments to opt for spending instruments instead of market instruments for programmatic purposes. The efficacy of spending instruments in addressing the ecological challenges is constrained further in several respects by structural features in its design. The structural limitations lie in the preferences they provide to foster particular activities, or to prompt certain taxpayers to act in response to the incentive. This feature has spawned rent-seeking behaviour, which in turn reinforces many other counter-intuitive behaviours that are discussed in-depth in this book.

Tax expenditures have been the subject of a great deal of attention that has gone beyond their apparent growth in number and size in recent times. When countries use tax expenditures as major fiscal policy instruments, the negative effects left in their wake are manifested in unanticipated revenue losses as well as in an erosion of their tax bases. Concerns about these negative effects as well as looming fiscal deficits have fostered a growing interest in budget processes and disciplines, including the need to impose restraints on tax expenditures. Swift et al highlight the experience of Argentina, Brazil, Columbia, Indonesia, Jamaica, and Mexico where the provision of generous tax incentives significantly eroded the tax bases of these countries. ${ }^{6}$ To address this, these countries had to embark on major structural reforms in the 1980 s to limit preferential incentives and thereby broaden their tax bases. ${ }^{7}$ Base broadening has also been at the centrepiece of tax reforms in many OECD countries as well.

\subsection{METHODOLOGY}

To rein in the excesses and some of the unintended effects associated with the use of tax expenditures, Stanley Surrey formulated the expenditure control theory (tax expenditure analysis). It in particular seeks to streamline the implementation of tax expenditure programmes with a view to enhancing their efficacy as tools for the implementation of policy, as well as to provide a reliable platform for tax reform. ${ }^{8}$ The precepts of Surrey's tax expenditure

6 Z.L. Swift, H.P. Brixi and C.M.A. Valenduc, 'Tax Expenditures: General Concept, Measurement, and Overview of Country Practices', in Ha Polackova Brixi, Christian M.A. Valenduc, and Zhicheng Li Swift (eds), Tax Expenditures - Shedding Light on Government Spending through the Tax System: Lessons from Developed and Transition Economies (Washington DC, The World Bank, 2004) 1.

7 Ibid.

8 Stanley S. Surrey, Excerpts from Remarks before The Money Marketeers on The U.S. Income Tax System - the Need for a Full Accounting, 15 November 1967 in United States Department of the Treasury, Annual Report of the Secretary of the Treasury on the State of the Finances for the Fiscal Year Ended June 30, 1968 (Washington DC, Government Printing Office, 1969) at 322; Stanley S. Surrey, Pathways to Tax Reform: 
analysis will therefore be used as the paradigm to evaluate different aspects of tax expenditure programmes examined throughout this work.

The primary focus of this book is centred on the issue of to what extent can the management of tax expenditures be undertaken so as to enhance their efficacy as instruments for the implementation of environmental policy? This issue is examined from different perspectives in three in-depth chapters. These chapters deal with the capacity and limits of tax expenditures in fostering R\&D and innovation, the prospects of funding environmental expenditures through revenues from earmarked taxes, and the re-structure of perverse environmental subsidies. Each one of these chapters in turn raises further issues that link the discussion therein back to the book's primary focus.

Surrey's work attempted to attribute an economic equivalence between tax expenditures and direct expenditures, and expressed a preference for the latter. The analysis will therefore evaluate the relationship as well as the relative merits of the two instruments in the implementation of environmental policy for the sake of completeness.

The book adopts a policy-oriented approach that examines options and ways that existing and potential public spending regimes fulfil different policy goals. Towards this end, the organisation of the book is structured along doctrinal concepts instead of on a country-by-country basis. While the latter approach is not without its advantages, the approach adopted provides a more solid platform for general observations while minimising repetitions. Though an inevitable element of subjectivity is involved in selecting the options to be discussed, the selections have been made with reference to both the conceptual interest of each option and their use in the contemporary context.

Although sections of the book embark on rather detailed discussions of the public spending instruments of selected OECD countries, it is not intended to provide a truly comprehensive coverage of the tax regimes of any country. The coverage of the tax provisions primarily serves to illustrate the operation of policy approaches that are otherwise discussed at a more abstract level. In order to analyse alternative legislative options, statutory rules embodying those options of course must be drawn from more than one country. Unfortunately, legislators do not design domestic public spending instruments with a view to presenting an illustrative spectrum of different regimes for the purposes of comparative legal research. Hence, the coverage of legislative alternatives cannot be structured in a purely systematic way. To maintain a reasonable degree of compactness, however, the book draws upon the experiences of Australia, Canada, the European Union, the United Kingdom, and

The Concept of Tax Expenditures (Cambridge, Mass., Harvard University Press, 1973) 30-49. 
the United States on relevant aspects of the matter as the primary reference group. These jurisdictions exhibit a relatively good sample of different public expenditure measures and policy approaches. However, occasional forays into the tax provisions of other countries' provisions will also be undertaken to fill in the context for alternatives that are not extensively used in any of those five jurisdictions.

Even though their use is pervasive across jurisdictions, the fact that different methodologies and assessments are used to determine what constitutes a tax expenditure makes any attempt to undertake international comparisons at any meaningful level a rather complicated task. For this reason, no attempt will be made to pursue such a task.

A matter that has detracted from the effectiveness of Surrey's tax expenditure analysis has been the issue of implicit tax expenditures or 'hidden' subsidies. The concerns that they pose are that their presence makes tax laws more complex and tax concessions less efficient. Two factors account for the existence of implicit subsidies. The first being tax preferences that result from judicial decisions that are not overturned by statute. ${ }^{9}$ The second stems from implicit subsidies that occur in the environmental policy context. This second category includes environmental externalities (or spill-over costs) that cannot be directly attributed to subsidies, but as any externality is an uncompensated cost, it effectively constitutes a subsidy paid by society. Myers and Kent distinguish implicit subsidies from formal subsidies on the following basis:

... a formal subsidy can cause problems because of what a government does, whereas an implicit subsidy in the form of an environmental externality causes problems because of what a government does not do. This has profound policy implications for government's policy responses when it seeks to correct subsidy problems. ${ }^{10}$

\subsection{CHAPTER OUTLINE}

This book examines the relative role that tax and direct expenditures play in the implementation of environmental policy. In particular, it explores the capacity and limits of using these instruments in financing environmental policy. It goes on to emphasise the role that the principles of policy instrument design play in enhancing the effectiveness of tax expenditures, in particular. Other themes examined in the book delve into the possibilities of strengthening the potential

9 Richard Krever, 'Analysing Implicit Tax Expenditures' (2011) 35 Melbourne University Law Review, 426-48.

10 Norman Myers and Jennifer Kent, Perverse Subsidies: How Tax Dollars Can Undercut the Environment and the Economy (Washington DC, Island Press, 2001) 14. 
of tax expenditures through approaches involving the earmarking of revenues, the reform of environmentally perverse subsidies, and the need for their use in the context of policy-instrument mixes.

To uncover the origins, nature and scope of tax expenditures, Chapter 2 sets the context for the analysis by embarking on a comprehensive review of the literature on its use as a tool for the implementation of government policy. Towards this end, the first part examines Surrey's original formulation of the tax expenditure concept which highlights the need for tax expenditure analysis as the basis for fiscal transparency and for efficient resource allocation. ${ }^{11}$ In the second part of this chapter, the issues outlined above will be examined in the wider context of the role that the substantive goals of a good tax system play in influencing policy instrument choice. Intermingled with this will be a detailed consideration of the complementary role that the elements of good design play in determining the efficacy of tax expenditure programmes.

The analysis in Chapter 3 focusses on the use of tax expenditures in the environmental policy context. The analysis starts off with an examination of the theoretical and legal basis for the use of tax expenditure programmes in this context. In extending the discussion from Chapter 2, it highlights some of the characteristics and limitations of tax expenditures that ought to be taken into consideration when choosing a policy instrument. It revisits the debate on the policy-instrument mix issue in the environmental context, in the wider context of considerations that have to be taken into account in ensuring that the spending instrument chosen is effective.

The analysis in Chapter 3 is then followed up in subsequent chapters with an examination of three in-depth scenarios that provide the context for addressing the central theme of the book.

There is a well-developed body of economic theory and empirical research in support of the role that tax and direct expenditures play in addressing positive externalities. Chapter 4 examines the use of tax and direct expenditures in fostering behavioural change. The cleantech sector is used as a case study to demonstrate how government spending fosters innovation and the take up of research and development. The significance of the object of the case study in this chapter is underscored by the fact that in the environmental policy context, innovation is not only a central driver in greening growth but also a key plank to any adaptation strategy.

Attempts by governments to rein-in ballooning public spending budgets makes expenditure cuts on environmental programmes the first casualty of the process. This has given environmental programs a stop-start nature and undermined policy certainty and effectiveness in the process. Chapter 5 explores

\footnotetext{
11 Ibid.
} 
the possibility of minimising such disruptions by undertaking a critical evaluation of alternative approaches to the implementation of public expenditures. Towards this end, the analysis in this chapter revisits the earmarking debate and examines the question of the extent to which the hypothecation of revenues from environmental taxes and charges can be relied on as a source of a secured stream of funds to finance environmental policy programmes on a sustained basis.

When tax expenditures are used in the environmental policy context to either provide preferences to certain activities or to certain taxpayers, they have the tendency of giving rise to unintended consequences that manifest in negative environmental outcomes and economic inefficiencies. Chapter 6 examines the challenges encountered in re-structuring subsidies that have become perverse from an environmental policy perspective. The pervasive dimensions of the challenges encountered in this context make a comprehensive examination of the issues in its entire spectrum a matter that goes beyond the scope of this book. Hence a forensic examination of employee car subsidies will be used as a proxy to highlight some of the challenges involved in the wider context of dismantling harmful subsidies in the transport sector. The analysis will be carried out in the context of a comparative jurisdictional study of the various approaches adopted in restructuring the perverse outcomes of employee car subsidies. Some of the wider lessons of implementing subsidy reform are then extrapolated from the experiences of the countries examined.

In concluding, Chapter 7 re-assesses the extent to which tax expenditure analysis has achieved its mission. It examines the evolution of tax expenditures in paving the way for new policy instruments into the environmental policy space. It then evaluates the extent to which tax expenditure analysis has played a role in shaping these new instruments and approaches. In the course of discussing some of these issues this chapter will also highlight possible areas for further research. 